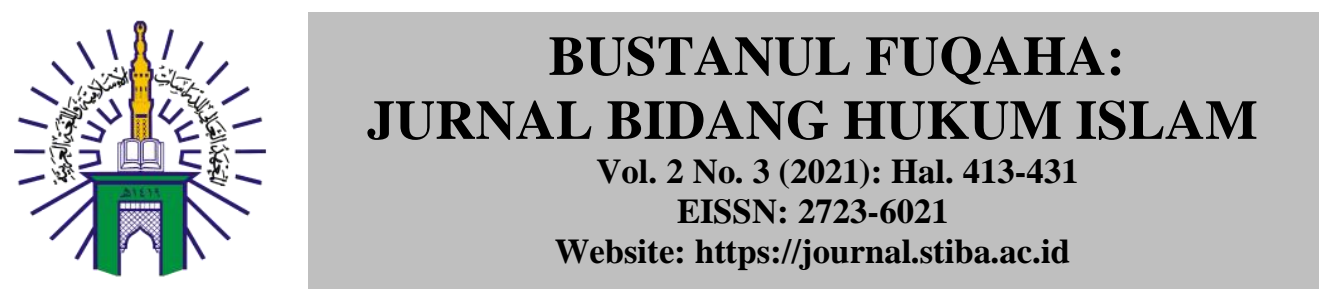

\title{
PUTUSNYA PERKAWINAN DAN AKIBATNYA DALAM FIKIH MUNAKAHAT (STUDI ANALISIS UNDANG-UNDANG NOMOR 1 TAHUN 1974 PASAL 38-41)
}

\section{THE TERMINATION OF MARRIAGE AND ITS CONSEQUNCES IN FIKIH MUNAKAHAT (ANALYSIS STUDY OF LAW NO.1 OF 1974 ARTICLES 38-41)}

\author{
Kasman Bakry \\ Sekolah Tinggi Ilmu Islam dan Bahasa Arab (STIBA) Makassar \\ Email: kasman@stiba.ac.id \\ Zulfiah Sam \\ Sekolah Tinggi Ilmu Islam dan Bahasa Arab (STIBA) Makassar \\ Email: zulfiahsam@stiba.ac.id \\ Jihan Vivianti Usman \\ Sekolah Tinggi Ilmu Islam dan Bahasa Arab (STIBA) Makassar \\ Email: jihanvivianti@gmail.com
}

\begin{tabular}{|c|c|}
\hline Keywords : & ABSTRACT \\
\hline $\begin{array}{l}\text { Fikih Munakahat, Law, } \\
\text { Marriage }\end{array}$ & $\begin{array}{l}\text { This research aims to find out and understand Fikih Munakahat and } \\
\text { the analysis of Law No. } 1 \text { of } 1974 \text { article } 38-41 \text { which discusses the } \\
\text { breakup of marriage. This research uses a type of qualitative } \\
\text { descriptive research, which focuses on the study of manuscripts and } \\
\text { texts with a theological-normative approach and a juridical approach. } \\
\text { The results showed that: First, the urgency of marriage in Islam that } \\
\text { lasted until now is the marriage of al-Wiladah, i.e. a man came to the } \\
\text { girl's parents to propose to her. Then he married her with his dowry; } \\
\text { Second, the basis of marriage law in Indonesia at the level of } \\
\text { application is contained in Law No. } 1 \text { of } 1974 \text { on Marriage and } \\
\text { Presidential Instruction No. } 1 \text { of } 1991 \text { on compilation of Islamic law } \\
\text { (KHI) applied in almost all marital problems, and the law is always } \\
\text { used as the basis and back of every judge in providing legal } \\
\text { interpretations and solutions to various problems of marriage law } \\
\text { today; Third, the legal consequences due to the termination of } \\
\text { marriage both in the perspective of Law No. } 1 \text { of } 1974 \text { in articles } 38 \\
41 \text { and in the perspective of Fikih Munakahat will have an impact on; } \\
\text { 1) children; 2) innate property; and 3) a living. }\end{array}$ \\
\hline Kata kunci : & ABSTRAK \\
\hline $\begin{array}{l}\text { Fikih Munakahat, Undang- } \\
\text { Undang, Perkawinan }\end{array}$ & $\begin{array}{l}\text { Penelitian ini bertujuan untuk mengetahui dan memahami Fikih } \\
\text { Munakahat dan analisis UU No. } 1 \text { Tahun } 1974 \text { pasal 38-41 yang } \\
\text { membahas putusnya perkawinan. Penelitian ini menggunakan jenis } \\
\text { penelitian deskriptif kualitatif, yang fokus pada studi naskah dan teks } \\
\text { dengan pendekatan teologi-normatif dan pendekatan yuridis. Hasil } \\
\text { penelitian menunjukkan bahwa: Pertama, urgensi perkawinan dalam } \\
\text { Islam yang berlangsung hingga sekarang adalah pernikahan al- } \\
\text { Wiladah, yakni seorang laki-laki datang kepada orang tua gadis untuk } \\
\text { melamarnya. Kemudian ia menikahinya disertai dengan maharnya; } \\
\text { Kedua, landasan hukum perkawinan di Indonesia pada tataran } \\
\text { aplikasinya terdapat dalam UU No. } 1 \text { Tahun } 1974 \text { tentang Perkawinan } \\
\text { dan Instruksi Presiden No. } 1 \text { Tahun } 1991 \text { tentang Kompilasi Hukum }\end{array}$ \\
\hline
\end{tabular}



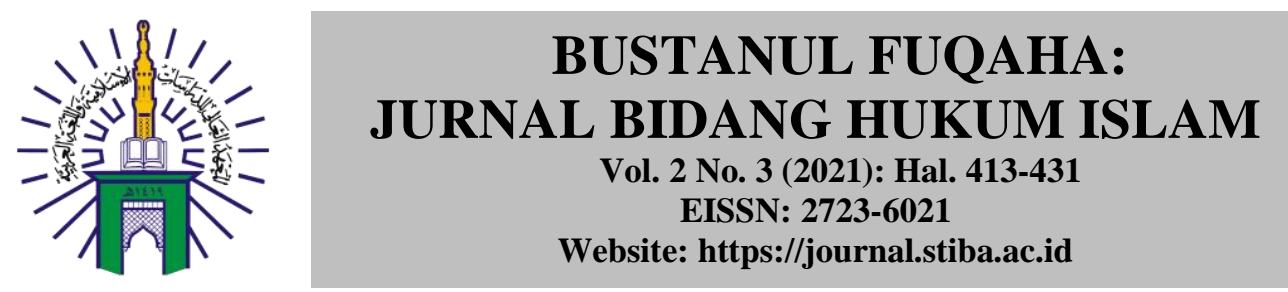

Islam (KHI) yang diterapkan hampir di semua permasalahan
perkawinan, dan undang-undang tersebut senantiasa dijadikan dasar
dan sandaran setiap hakim dalam memberikan interpretasi hukum dan
solusi terhadap berbagai problem hukum perkawinan saat ini; Ketiga,
konsekuensi hukum akibat putusnya perkawinan baik dalam perspektif
UU No. 1 Tahun 1974 pada pasal 38-41 maupun menurut perspektif
Fikih Munakahat akan konsekuansi tersebut berdampak pada; 1) anak;
2) harta bawaan; dan 3) nafkah.

Diterima: 2 September 2021; Direvisi: 12 Oktober 2021; Disetujui: 10 November 2021; Tersedia online: 3 Desember 2021

How to cite: Kasman Bakry, Zulfiah Sam, Jihan Vivianti Usman, "Putusnya Perkawinan dan Akibatnya dalam Fikih Munakahat (Studi Analisis UU RI No. 1 Tahun 1974 Pasal 38-41)", BUSTANUL FUQAHA: Jurnal Bidang Hukum Islam Vol. 2, No. 3 (2021): 413-431. doi: 10.36701/bustanul.v2i3.401.

\section{PENDAHULUAN}

Manusia merupakan makhluk sosial yang saling membutuhkan satu sama lain. Sebagaimana seorang pria membutuhkan seorang wanita, dan begitu juga sebaliknya wanita membutuhkan seorang pria. Semua makhluk ciptaan Allah swt. di dunia ini, diciptakan berpasang-pasangan. Begitu juga manusia diciptakan secara berpasangan yaitu pria dan wanita. Sebagaimana Allah berfirman dalam Q.S. al-Żariyat/51:49,

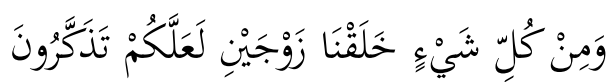

Terjemahnya:

Dan segala sesuatu Kami ciptakan berpasang-pasangan supaya kamu mengingat kebesaran Allah ${ }^{1}$.

Seorang pria dan wanita yang sudah dewasa akan memiliki keinginan untuk hidup bersama dengan yang berlainan jenis kelaminnya, hidup bersama antara pria dan wanita dalam suatu ikatan dengan memenuhi syarat-syarat tertentu disebut perkawinan. Hidup bersama dilakukan untuk membentuk keluarga dalam ikatan perkawinan yang sah sesuai dengan norma agama dan aturan yang berlaku di Indonesia.

Perkawinan tidak hanya mengandung unsur hubungan manusia tetapi juga menyangkut hubungan keperdataan, dan mengandung unsur sakralitas yaitu hubungan antara manusia dengan Tuhannya ${ }^{2}$. Untuk melakukan sebuah perkawinan harus memenuhi syarat maupun rukun perkawinan, bahwa perkawinan harus diberitahukan dan dicatat serta dilakukan dihadapan pegawai pencatat perkawinan untuk mendapatkan kepastian hukum.

Menurut Abū A'lā al-Maudūdī sebagaimana dikutip oleh Rahmat Hakim dalam bukunya yang berjudul Hukum Perkawinan Islam bahwa, "Salah satu prinsip hukum perkawinan Islam adalah perkawinan itu harus dipertahankan agar tidak terjadi

\footnotetext{
${ }^{1}$ https://tafsirq.com/51-az-zariyat/ayat-49
} 


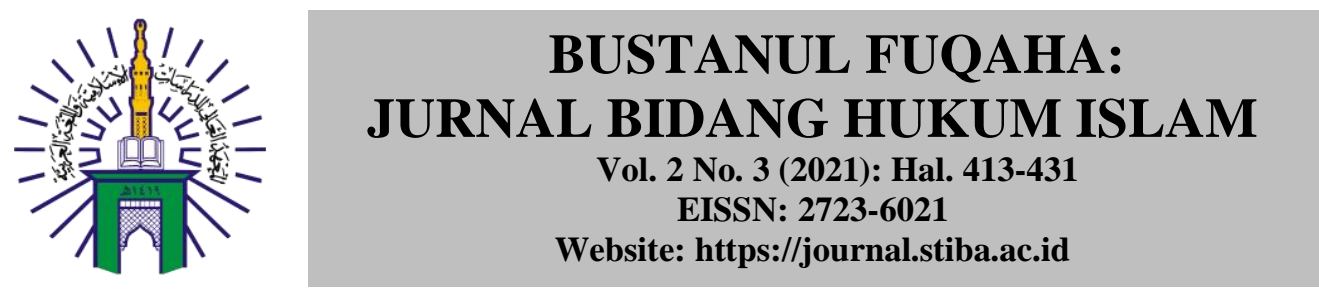

\section{BUSTANUL FUQAHA}

Jurnal Bidang Hukum Islam

perceraian" ${ }^{2}$. Suatu perkawinan dapat putus dan berakhir karena berbagai hal ${ }^{3}$. Putusnya ikatan bisa berarti salah seorang di antara keduanya meninggal dunia, antara pria dengan wanita sudah bercerai, dan salah seorang di antara keduanya pergi ke tempat yang jauh kemudian tidak ada beritanya sehingga pengadilan menganggap bahwa yang bersangkutan telah meninggal. Berdasarkan semua itu, ikatan suami istri dapat berarti sudah putus dan atau bercerainya antara seorang pria dengan seorang wanita yang diikat oleh tali perkawinan ${ }^{4}$.

Secara sederhana, putus artinya tidak tersambung lagi atau tidak ada hubungan lagi dari yang sebelumnya tersambung atau terhubung. Dalam konteks perkawinan, maka putusnya perkawinan adalah istilah hukum yang digunakan dalam Undang-undang perkawinan untuk menjelaskan "Perceraian" atau berakhirnya hubungan perkawinan antara seorang laki-laki dengan seorang perempuan yang selama ini hidup sebagai suami istri. Untuk maksud perceraian, maka dalam fikih digunakan istilah furqah ${ }^{5}$.

Tidak dapat dipungkiri bahwa untuk mempertahankan suatu keharmonisan dalam perkawinan yang sesuai dengan tujuannya dan ketentuan pergaulan suami istri seperti yang diharapkan oleh agama Islam itu tidaklah mudah. Sebab, di dalam rumah tangga akan banyak terjadi cobaan dan rintangan. Begitu pula di dalam ajaran syariat Islam bahwa seorang yang hidup tidak terlepas dari cobaan Allah swt. Salah satu bentuk cobaan terberat dalam sebuah perkawinan adalah dengan adanya kematian orang yang tercinta.

Putusnya perkawinan karena kematian terjadi karena salah satu pihak dalam perkawinan meninggal dunia apakah itu suami atau istri. Putusnya perkawinan karena kematian merupakan kejadian yang berada diluar kehendak atau kuasa dari para pihak dalam perkawinan.Tidak terdapat campur tangan dari pasangan yang hidup lebih lama ataupun campur tangan dari pengadilan. Putusnya perkawinan karena kematian sepenuhnya merupakan kehendak atau kuasa dari Tuhan, dan putusnya perkawinan karena kematian lazim disebut dalam masyarakat kita dengan istilah cerai mati.

Perceraian merupakan bagian dari perkawinan, sebab tidak ada perceraian tanpa adanya perkawinan terlebih dahulu. Perkawinan merupakan awal dari bersama antara seorang pria dengan wanita yang di atur dalam hukum agama serta peraturan perundang-undangan dalam suatu negara. Sedangkan perceraian merupakan akhir dari kehidupan bersama suami istri tersebut. Akan tetapi, setiap orang menghendaki agar perkawinan yang dilaksanakannya itu tetap utuh sepanjang hayatnya. Namun, realitasnya tidak sedikit perkawinan yang dibina dengan susah payah itu harus berakhir dengan suatu perceraian.

Perceraian dalam hukum Islam pada prinsipnya dibolehkan, akan tetapi hal ini dibenci oleh Allah swt. Perceraian menjadi solusi terakhir yang boleh ditempuh manakala kehidupan rumah tangga tidak bisa dipertahankan lagi. Islam menganjurkan agar sebelum terjadi perceraian, maka ditempuh usaha-usaha perdamaian antara kedua

\footnotetext{
${ }^{2}$ Rahmat Hakim, Hukum Perkawinan Islam (t. Cet; Bandung: Pustaka Setia, 2000), h. 145.

${ }^{3}$ Tihami dan Sohari Sahrani, Fikih Munakahat (t. Cet; Jakarta: PT.Rajawali Pers, 2010),h. 229.

${ }^{4}$ Zakiyuddin Sya'ban, Az Zawaj wa Ath Thalaq Fil Islam, (Riyadh: Dar Al Maktabah, 2009). H. 74-75.

5 Amir Syarifuddin, Hukum Perkawinan Islam di Indonesia (t. Cet; Jakarta: Kencana, 2007), h. 189
} 


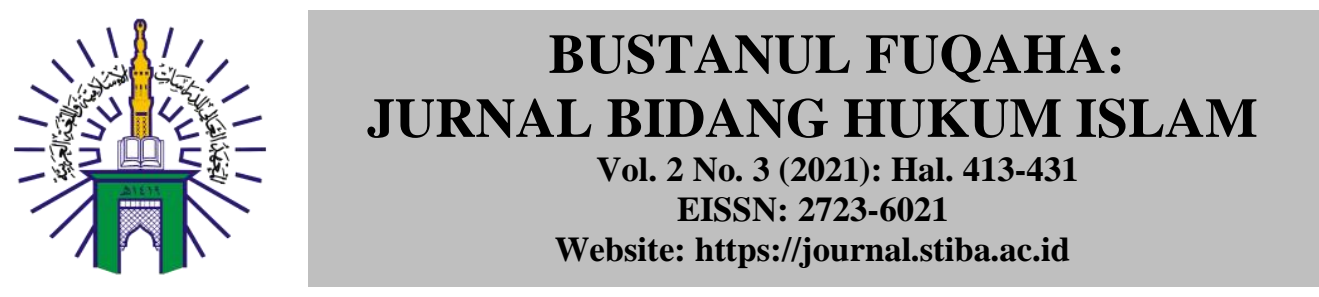

\section{BUSTANUL FUQAHA}

Jurnal Bidang Hukum Islam

belah pihak, karena ikatan perkawinan adalah ikatan yang paling suci dan kokoh ${ }^{6}$. Hal ini sejalan dengan prinsip perkawinan bahwa perceraian itu harus dipersulit, dan ini sesuai dengan hadis Rasulullah saw. yang menyatakan bahwa talak atau perceraian adalah perbuatan yang halal yang paling dibenci oleh Allah swt., sebagaimana bunyi hadis berikut ini, yang berbunyi:" "Mengabarkan kepada kami Kasīir bin „,Ubaid alHimșiyyi berkata: mengabarkan kepada kami Muhammad bin Khālid, dari ,Ubaidillah bin al-Walìd al-Wașsāfiyyi, dari Muḥārib bin Dis̄āri, dari ,Abdullah bin ,Umarberkata: berkata Rasulullah saw. "Perbuatan halal yang paling dibenci Allah ialah cerai". Hadis riwayat Abū Dāud, Ibnu Mājah, dan disahihkan oleh Hākim, dan dirajihkan oleh Abū Hātim secara mursāl."

Pada kalimat yang berbunyi, "Perbuatan halal yang dibenci oleh Allah adalah talak", maka ini merupakan keringanan dari Allah swt. dan merupakan hukum yang disyariatkan dalam kondisi darurat, yaitu ketika hubungan suami istri sudah tidak dapat dipertahankan lagi, dan keduanya sudah tidak lagi saling mencintai dan saling mengharapkan, maka jalan perceraian adalah jalan yang terbaik.

Berdasarkan latar belakang masalah yang telah diuraikan di atas, maka perlu dibuat rumusan masalah sebagai berikut: (1) Bagaimana urgensi perkawinan dalam Islam?; (2) Bagaimana landasan hukum perkawinan di Indonesia?; dan (3) Bagaimana konsekuensi hukum akibat putusnya perkawinan?. Adapun tujuan penelitian yang akan dicapai adalah: (a) Untuk mengetahui urgensi perkawinan dalam Islam; (b) Untuk mengetahui landasan hukum perkawinan di Indonesia; dan (c) Untuk mengetahui konsekuensi hukum akibat putusnya perkawinan.

Sesuai dengan objek peneletian ini, maka jenis penelitian yang akan digunakan adalah penelitian kepustakaan (library research) yang bersifat kualitatif, yaitu dengan melakukan penelitian terhadap sumber-sumber tertulis, baik media cetak maupun elektronik. Oleh karena itu, pembahasan putusnya perkawinan dan akibatnya dalam fikih munakahat sebagai sesuatu yang telah diketahui, dapat dipahami dan dideskripsikan, untuk selanjutnya dianalisis dalam perspektif UU RI No 1 Tahun 1974, secara khusus pada pasal 38-41 dengan menggunakan pendekatan teologi, normatif dan yuridis.

Dalam upaya membandingkan penelitian ini, maka penting bagi penulis untuk mengkaji penelitian-penelitian terdahulu. Berdasarkan hasil penelitian dalam berbagai literatur, baik perpustakaan maupun jurnal berbasis online, penulis menemukan beberapa penelitian yang serupa namun tidak sama dengan penelitian ini di antaranya:

1. Penelitian yang berjudul, "Kedudukan Hukum Putusnya Perkawinan dalam Putusan Hakim yang Dijatuhkan Pada Saat Istri Hamil (Studi KasusPerkara Pengadilan Agama Depok No. 532/Pdt.G/2008/PA.Bgr, No 19/Pdt.G/2008/PA.Ngr, dan no 1974/pdt.G/2009/PA.Jr)." Penelitian ini membahas tentang kedudukan seorang hakim yang memutuskan sebuah perkawinan dalam keadaan istri tersebut sedang hamil. Penelitian ini lebih difokuskan pada putusan

${ }^{6}$ Ahmad Rofiq, Hukum Islam di Indonesia (Cet. I; Jakarta: Raja Grafindo, 1995), h. 268.

7 Abī Abdillah Muhammad bin Yaz̄̄d al-Qazwīn̄i, Sunan Ibnu Mājah, Juz 1. (Cet. II; Riyāḍ: Syarikah al-Ṫibā"ah al-,,Arabiyyah al-Su"ūdiyyah, 1404 H/ 1984 M), h. 373. 


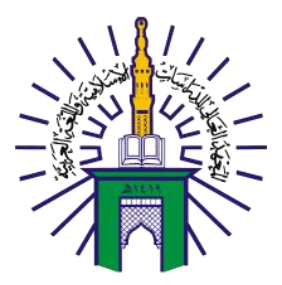

\section{BUSTANUL FUQAHA: \\ JURNAL BIDANG HUKUM ISLAM \\ Vol. 2 No. 3 (2021): Hal. 413-431 \\ EISSN: 2723-6021 \\ Website: https://journal.stiba.ac.id}

\section{BUSTANUL FUQAHA \\ Jurnal Bidang Hukum Islam}

seorang hakim dalam kasus yang terjadi di Pengadilan Agama Depok ${ }^{8}$.

2. Penelitian yang berjudul, "Faktor-Faktor yang Mengakibatkan Perceraian dalam Perkawinan." Penelitian ini bertujuan untuk mengetahui faktor yang mengakibatkan terjadinya perceraian yang secara umum ataupun khusus terjadi di kalangan masyarakat. Penelitian ini secara khusus tertuju pada masyarakat non muslim. Titik perbedaannya adalah pada penelitian ini lebih terfokus pada pembahasan yang berkaitan tentang sebab terjadinya perceraian secara khusus dalam beberapa masalah ${ }^{9}$.

3. Penelitian yang berjudul, "Fasakh Nikah Menurut Al Imam Al Syafi'i Relevansinya dengan Kompilasi Hukum Islam." Penelitian ini membahas pandangan al-Imam alSyafi'i tentang fasakh nikah dalam Kompilasi Hukum Islam (KHI) dan bagaimana pendapat al-Imam al-Syafi'i tersebut dengan kompilasi Hukum Islam. Penelitian ini lebih fokus pada pandangan al-Imam al-Syafi'i akan hukum fasakh serta fasakh dalam kompilasi Hukum Islam ${ }^{10}$.

Dari ketiga hasil penelitian di atas semuanya relevan dengan pengkajian seputar perkawinan dan perceraian. Namun, belum mengkaji perspektif UU RI No. 1 Tahun 1974, secara khusus pada pasal 38-41, terlebih dalam tinjauan analisis fikih munakahat. Dengan demikian, pada titik ini nilai kebaruan pengkajian penulis.

\section{PEMBAHASAN}

\section{Perkawinan dalam Fikih Munakahat}

Perkawinan atau yang dikenal dalam ilmu fikih dengan sebutan pernikahan, bemakna suatu akad atau perjajian mengikat antara seorang laki-laki dengan perempuan untuk menghalalkan hubungan kelamin antara keduanya dengan suka rela dan dengan kerelaan keduanya merupakan suatu kebahagian hidup berkeluarga yang diliputi rasa kasih sayang dan ketentraman (sakinah) dengan cara-cara yang di ridhai Allah swt ${ }^{11}$. Secara etimologi, kata kawin menurut bahasa sama dengan kata nikah, atau kata zawaj. Nikah artinya $a l$-Wath' $u$ yang berarti bejalan di atas, melalui, memijak, memasuki, menaiki, menggauli, dan bersetubuh atau bersenggama ${ }^{12}$.

Syekh Kamil Muhammad 'Uwaidah mengungkapkan menurut bahasa bahwa nikah berarti penyatuan, diartikan juga sebagai akad atau hubungan badan, selain itu, ada juga yang mengartikannya dengan percampuran ${ }^{13}$. Al-Șan'āni dalam kitabnya memaparkan bahwa nikah menurut pengertian bahasa ialah penggabungan dan saling memasukkan serta percampuran. Kata nikah itu dalam pengertiannya adalah persetubuhan dan akad.

\footnotetext{
${ }^{8}$ Noorish Zulfina, Kedudukan Hukum Putusnya Perkawinan dalam Putusan Hakim yang Dijatuhkan pada saat istri Hamil (Studi Kasus Perkara Pengadilan Agama Depok No. 532/Pdt.G/2008/PA.Bgr, No 19/Pdt.G/2008/PA.Ngr, dan no 1974/pdt.G/2009/PA.Jr) . Skripsi, Universitas Indonesia 2012.

9 Armansyah Matondang, "Faktor-Faktor yang Mengakibatkan Perceraian dalam Perkawinan" Jurnal Ilmu Pemerintahan dan Sosial Politik UMA 2, No. 2 (2014).

${ }^{10}$ Aqmal, Fasakh Nikah Menurut Imam Asy Syafi'i Relevansinya dengan Kompilasi Hukum Islam, Skripsi, Universitas Negeri Alauddin Makassar, 2012.

${ }^{11}$ Sayyid Sabiq, Fiqh as Sunnah, (Daar Al Bayan: Kuwait, 1971), h. 175.

${ }^{12}$ Ahmad Warson al-Munawwir, kamus al-Munawwir Arab-Indonesia Terlengkap (t.Cet; Yogyakarta: Pustaka Progressif, 1997), h. 1461

${ }^{13}$ Syekh kamil Muhammad Uwaidah, Fiqh al-Nisā, terj.Muhammad Abdul Ghofar, Fikih wanita (Cet. X; Jakarta: Pustaka al-Kautsar, 2002), h. 375.
} 


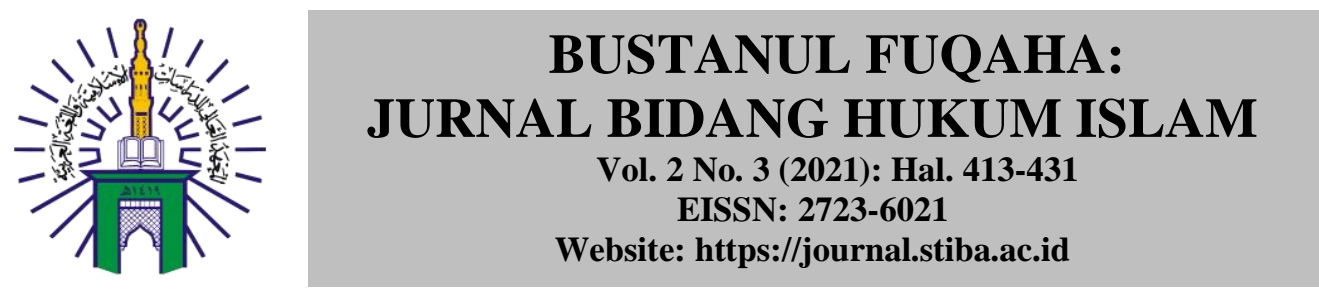

\section{BUSTANUL FUQAHA}

Jurnal Bidang Hukum Islam

Nikah merupakan hakekat bagi keduanya, dan kata nikah itu musytarak bagi keduanya. Sehingga, kata nikah banyak digunakan dalam akad karena besifat syar' $i$, oleh sebab itu kata nikah tidak dimasukan dalam Al-Qur'an, kecuali dalam hal akad ${ }^{14}$. Dengan demikia, kata nikah secara bahasa dapat diartikulasikan sebagai penyatuan, penggabungan dan atau saling memasukan serta percampuran.

Secara terminologi, menurut Sayuti Țalib, nikah ialah perjanjian suci membentuk keluarga antara seorang laki-laki dengan seorang perempuan ${ }^{15}$. Sedangkan Zahry Hamid merumuskan nikah menurut syara ialah akad (ijab kabul) antara wali calon istri dan calon mempelai laki-laki dengan ucapan tertentu dan memenuhi rukun serta syaratnya ${ }^{16}$. Imam al-Jurjani mengatakan bahwa nikah diartikan sebagai sebuah akad atas kepemilikan terhadap manfaat kemaluan yang dilakukan dengan sengaja ${ }^{17}$.

Pernikahan adalah pondasi sebuah keluarga dan keluarga adalah dasar terbentuknya sebuah masyarakat. Masyarakat yang di dalamnya banyak pernikahan, penduduknya akan bertambah dan pendapatannya bertambah pula. Sebaliknya masyarakat yang di dalamnya sedikit terjadi pernikahan maka penduduknya akan berkurang sehingga masyarakat itupun tidak berkembang. Oleh sebab itu, pernikahan merupakan satusatunya upaya dalam menambah populasi umat Nabi Muhammad saw. Sebagaimana sebuah kisah yang terjadi pada zaman Rasulullah saw., dari Ma'qil bin Yasar ra. berkata, "Datang seorang pria kepada Nabi saw. dan berkata, "Aku menemukan seorang wanita yang cantik dan memiliki martabat tinggi namun ia mandul apakah aku menikahinya?", Nabi saw. menjawab, “Jangan!", kemudian pria itu datang menemui Nabi saw. kedua kalinya dan Nabi saw. tetap melarangnya, kemudian ia menemui Nabi saw. yang ketiga kalinya maka Nabi saw. berkata, "Nikahilah wanita yang sangat penyayang dan yang mudah beranak banyak (subur) karena aku akan berbangga dengan kalian dihadapan umat-umat yang lain"18.

Adapun di antara hikmah disyariatkannya pernikahan yaitu demi menjaga kehormatan, sebagai sarana berkembang biak, dan penjagaan terhadap keberadaan dan eksistensi manusia, membentuk keluarga yang dengannya akan mendatangkan kebahagiaan dan ketenangan. Selain itu pernikahan adalah suatu wadah bagi sifat alami manusia untuk saling membutuhkan pasangan. Dengan demikian, adanya pernikahan merupakan sesuatu yang tidak bisa dinafikan dan dipungkiri keberadaannya bagi manusia yang memiliki akal sehat dan fitrah yang terjaga.

\section{Hukum Disyariatkan Perkawinan dalam Islam}

Pernikahan disyariatkan berdasarkan Al-Qur'an dan hadis-hadis. Dalil-dalil dari AlQur'an cukup banyak, di antaranya dalam Q.S. Al-Nur/24:32, yang berbunyi,

14 Sayyid al-Imām Muhammad bin Ismail al-Șan'āni, Subul al-Salam fi al-Syarh Bulugu alMarāmmin Jāmō’ Adillati al-Ahkām, Juz 3 (t. Cet; Kairo: Dar Ikhya" al-Turas al-Islami, 1960), h. 350.

${ }^{15}$ Sayuti Talib, Hukum Kekeluargaan Indonesia (Cet. V; Jakarta: UI Press, 1986), h.47.

${ }^{16}$ Zahry Hamid, Pokok-Pokok Hukum Nikah Islam dan Undang-Undang Nikah di Indonesia (t. Cet; Yogyakarta: Bina Cipta, 1978), h. 1.

${ }^{17}$ Ali bin Sa'id al-Ghamidi, Dalīl al-Mar'ah al-Muslimah, terj. Ahmad Syarif, dkk, Fikih Wanita (Cet. IX; Solo: Aqwam, 1438 H/2017 M), h. 283.

${ }^{18}$ HR Abu Dawud 2/220 no 2050 dan ini adalah lafalnya, Ibnu Hibban 9/363,364, An-Nasaai 6/65, berkata Syaikh Al-Albani , "Hasan Shahih" 

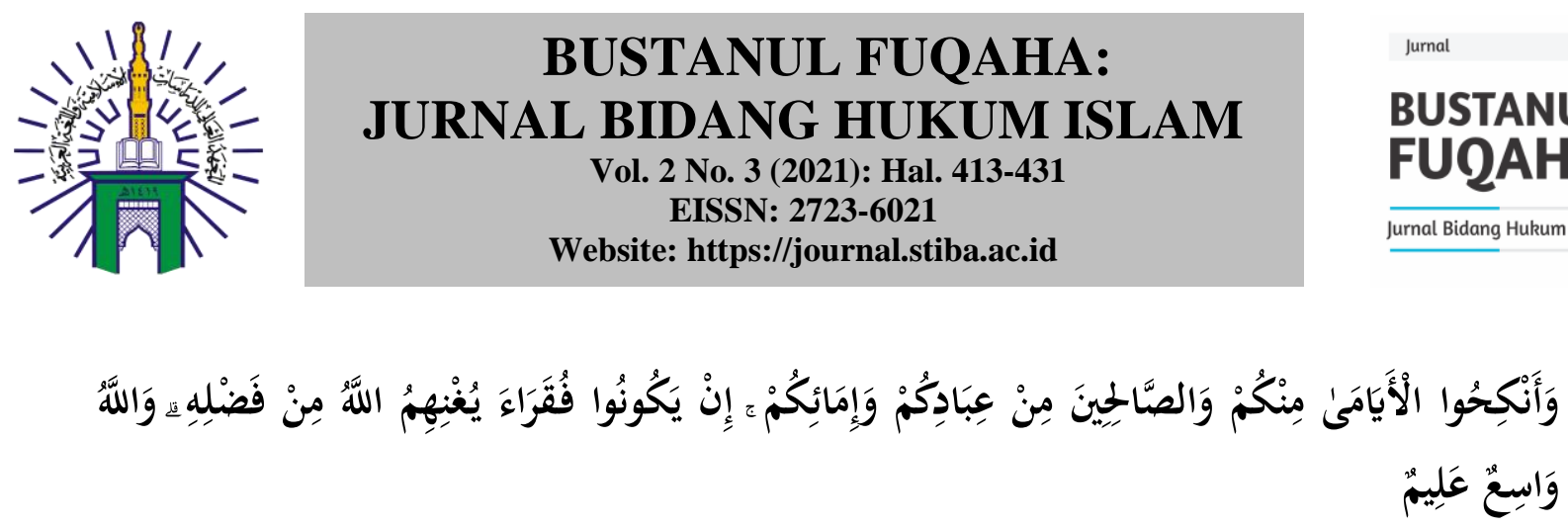

Terjemahnya:

Dan nikahkanlah orang-orang yang sendirian di antara kamu dan orang- orang yang patut (nikah) dari hamba-hamba sahayamu yang perempuan. Jika mereka miskin maka Allah akan membuat mereka kaya dengan karunia-Nya, dan Allah Maha luas (pemberian-Nya) lagi Maha mengetahui ${ }^{19}$.

Selanjutnya dalam Q.S. Al-Nisa/4:3, yang berbunyi,

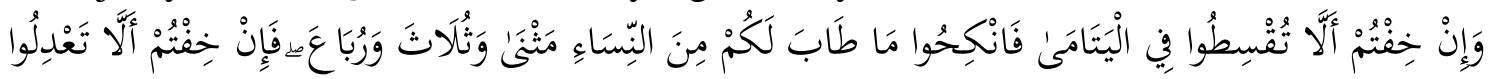

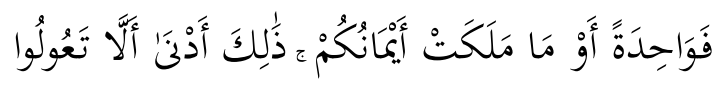

Terjemahnya:

Dan jika kamu takut tidak dapat berlaku adil terhadap (hak-hak) perempuan yatim (bila kamu mengawininya) maka nikahilah wanita- wanita (lain) yang kamu senangi: dua, tiga atau empat, kemudian jika kamu takut tidak akan dapat berlaku adil maka (nikahilah) seorang saja, atau budak-budak yang kamu miliki, yang demikian itu lebih memungkinkan untuk tidak berbuat aniaya ${ }^{20}$.

Adapun dalil dari hadis, berbunyi, Dari Abdullah bin Mas'ud ra.: Rasulullah saw. bersabda, "Wahai para pemuda, barang siapa di antara kamu yang telah mampu maka menikahlah karena pernikahan akan lebih bisa menjaga mata dan kemaluan. Dan barang siapa yang belum mampu maka berpuasalah karena puasa merupakan benteng penjagaan" 21 .

Dalam hadis lain, Rasulullah saw. bersabda: "Demi Allah, sungguh aku adalah orang yang paling bertakwa dan paling takut kepada Allah. Meski demikian, aku tetap berpuasa dan berbuka, tetap sholat malam dan tidur, serta tetap mengawini wanita. Barang siapa tidak suka terhadap sunnahku maka dia bukan termasuk umatku."

Adapun hukum menikah bisa berbeda-beda tergantung pada situasi dan kondisi dari individu yang bersangkutan. Para ulama membagi hukum menikah menjadi beberapa macam, yaitu: ${ }^{22}$

Wajib, menikah menjadi wajib bagi pelakunya, jika ia yakin tidak mampu menjaga kehormatannya (bahkan dengan berpuasa), serta khawatir akan terjerumus kepada

${ }^{19}$ https://tafsirq.com/24-an-nur/ayat-32

${ }^{20} \mathrm{https}$ //tafsirq.com/4-an-nisa/ayat-3

${ }^{21}$ Hadits shahih: Diriwayatkan oleh Ahmad (I/424, 425, 432), al-Bukhari (no. 1905, 5065, 5066), Muslim (no. 1400), at-Tirmidzi (no. 1081), an-Nasa-i (VI/56, 57), ad-Darimi (II/132) dan al-Baihaqi (VII/ 77), dari Shahabat 'Abdullah bin Mas'ud radhiyallaahu 'anhu

${ }^{22}$ Imam Abī al-Walīd Muhammad bin Ahmad bin Muhammad bin Ahmad bin Rusydi al-Qurtubī al-Andalusi, Bidāyah al-Mujtahid wa Kifayāh al-muqtașid, Juz 2 (Cet. I; al-Qāhirah: Dar ibn al-Jauzi, 2004), h. 2. 


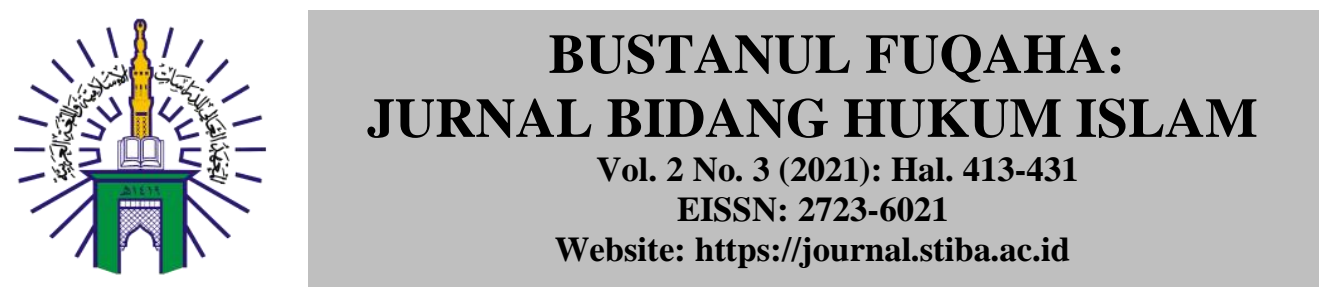

\section{BUSTANUL FUQAHA}

Jurnal Bidang Hukum Islam

perbuatan yang diharamkan jika ia tidak menikah. Dan ia juga mampu melakukannya, baik mampu menafkahi istrinya lahir batin, mampu membayar mahar, memberikan hakhak istri, dan lain sebagainya. Maka bagi orang yang seperti ini, hukum menikah menjadi wajib demi terjaganya ia dari perbuatan yang diharamkan.

Haram, menikah menjadi haram bagi orang yang hendak melakukannya, jika ia yakin dirinya akan menzalimi pasangannya atau bahkan membahayakannya. Seperti seorang laki-laki yang memiliki penyakit kelamin, atau laki-laki yang yakin tidak akan mampu menunaikan kewajibannya sebagai suami setelah menikah, dan sebagianya. Termasuk yang diharamkan juga adalah seorang suami yang yakin tidak akan mampu berbuat adil jika ia menikah lagi (berpoligami).

Makruh, makhruh bagi seseorang untuk menikah ketika dirinya khawatir terjerumus kepada perbuatan dosa, namun masih mampu menahannya dan ia khawatir tidak mampu menunaikan hal-hak yang menjadi hak bagi pasangannya, seperti nafkah, pergaulan yang baik dan sebagainya.

Sunah, menurut jumhur ulama, dianjurkan menikah bagi seseorang ketika ia tidak punya kekhawatiran akan terjerumus pada perbuatan haram (zina, dan yang lainnya), serta masih mampu menjaga dirinya, dan ia telah memenuhi kriteria mampu menikah. Sedangkan menurut mazhab Syafi'i, orang yang berada dalam kondisi ini hukumnya mubah (boleh) melakukan pernikahan dan bukan sunah.

Para ulama menyatakan bahwa lebih utama bagi orang yang telah mampu untuk menikah. Kecuali orang-orang yang disibukkan dengan amal-amal ibadah atau belajar ilmu-ilmu syar'i. Hal ini dikarena dengan menikah, seseorang akan lebih terjaga kehormatannya, dan menjauhkannya dari berbuat keji.

\section{Landasan Hukum Perkawinan di Indonesia}

\section{Undang-Undang No. 1 Tahun 1974 tentang Perkawinan}

Dasar-dasar hukum perkawinan terdapat di dalam pasal 28 B ayat (1) UndangUndang Dasar 1945 yang berbunyi "Setiap orang berhak membentuk keluarga dan melanjutkan keturunan melalui perkawinan yang sah. "Berdasarkan pernyataan tersebut dapat diketahui bahwa tujuan dan cita-cita negara Indonesia adalah untuk memajukan kesejahteraan rakyatnya dengan memberikan hak kepada setiap rakyatnya dengan memberikan hak untuk mempertahankan kehidupannya yang berarti mempunyai hak untuk melanjutkan keturunan, dan setiap orang mempunyai hak untuk membentuk sebuah keluarga. Hal tersebut merupakan hak asasi manusia yang tidak dapat ditawartawar lagi. Selain itu, dasar hukum perkawinan juga terdapat di dalam Undang-Undang No. 1 Tahun 1974 tentang Perkawinan yang diatur pada Bab I tentang Dasar Perkawinan yang terdiri dari lima pasal, yaitu dari pasal 1 sampai dengan pasal $5^{23}$.

Di dalam Pasal 1 Undang-Undang No. 1 Tahun 1974 tentang Perkawinan mengenai pengertian perkawinan yang menyebutkan bahwa: "Ikatan lahir batin seorang pria dengan seorang wanita sebagai suami istri dengan tujuan membentuk keluarga (rumah

${ }^{23}$ Tim Redaksi Nuansa Aulia, Kompilasi Hukum Islam (Cet. VII; Bandung: CV.Nuansa Aulia, 2017), h. 73-75. 
tangga) yang bahagia dan kekal berdasarkan Ketuhanan yang Maha Esa." Kemudian, Pasal 2 ayat (1) Undang-Undang No. 1 Tahun 1974 tentang perkawinanan mengenai syarat sahnya suatu perkawinan yang menyebutkan bahwa: "Perkawinan adalah sah, apabila dilakukan menurut hukum masing-masing agamanya dan kepercayaannya itu." dan di dalam ayat (2) menyebutkan bahwa: "Tiap-tiap perkawinan dicatat menurut peraturan perundang-undangan yang berlaku." Dengan perumusan pada pasal 2 ayat (1) ini, tidak ada perkawinan diluar hukum masing-masing agamanya dan kepercayaannya. Yang dimaksud hukum masing-masing agamanya dan kepercayaannya itu termasuk ketentuan perundang-undangan yang berlaku bagi golongan agamanya dan kepercayaannya itu sepanjang tidak bertentangan atau tidak ditentukan lain dalam undang-undang ini.

Selanjutnya, Pasal 3 ayat (1) Undang-Undang No. 1 Tahun 1974 menyebutkan bahwa: "Pada azasnya dalam suatu perkawinan seorang pria hanya boleh mempunyai seorang istri. Seorang wanita hanya boleh mempunyai seorang suami." Dalam ayat (2) menyebutkan bahwa: "Pengadilan, dapat memberi izin kepada seorang suami untuk beristri lebih dari seorang apabila dikehendaki oleh pihak-pihak yang bersangkutan."

Pasal 4 ayat (1) Undang-Undang No. 1 Tahun 1974 menyebutkan bahwa: "Dalam hal seorang suami akan beristri lebih dari seorang, sebagaimana tersebut dalam pasal 3 ayat (2) Undang-Undang ini, maka ia wajib megajukan permohonan kepada pengadilan di daerah tempat tinggalnya." Dalam ayat (2) menyebutkan bahwa: "Pengadilan di maksud ayat (1) pasal ini hanya memberi izin kepada seorang suami yang akan beristri lebih dari seorang apabila: a) Istri tidak dapat menjalankan kewajibannya sebagai istri; b) Istri mendapat cacat badan atau penyakit yang tidak dapat disembuhkan; c) Istri tidak dapat melahirkan keturunan.

Pasal 5 ayat (1) Undang-Undang No. 1 Tahun 1974 menyebutkan bahwa: "Untuk dapat mengajukan permohonan kepada pengadilan, sebagaimana dimaksud dalam pasal 4 ayat (1) undang-undang ini, harus dipenuhi syarat-syarat sebagai berikut: a) Adanya persetujuan dari istri/istri-istri; b) Adanya kepastian bahwa suami dapat menjamin keperluan-keperluan hidup istri-istri dan anak-anak mereka; c) Adanya jaminan bahwa suami akan berlaku adil terhadap istri-istri dan anak-anak mereka." Dalam ayat (2) menyebutkan bahwa: "Persetujuan yang dimaksud pada ayat (1) huruf a pasal ini tidak diperlukan bagi seorang suami apabila istri/istri-istrinya tidak mungkin dimintai persetujuannya dan tidak dapat menjadi pihak dalam perjanjian, atau apabila tidak ada kabar dari istrinya selama sekurang-kurangnya 2 (dua) tahun, atau karena sebab-sebab lainnya yang perlu mendapat penilaian dari hakim pengadilan."

\section{Inpres No. 1 Tahun 1991 Tentang Kompilasi Hukum Islam}

Secara harfiah, kompilasi berarti suatu kumpulan atau himpunan. Dalam bahasa Inggris ada istilah Compilation of Laws atau himpunan Undang-Undang ${ }^{24}$. Dalam istilah lain, kompilasi merupakan suatu koleksi, bila dikaitkan dengan hukum, maka dapat diartikan sebagai himpunan materi hukum dalam satu buku. Dengan demikian Kompilasi Hukum Islam (KHI) adalah suatu himpunan bahan-bahan Hukum Islam

${ }^{24}$ John. M. Echols dan Hasan Shaldy, English-Indonesia Dictionary (t. Cet; Ithaca dan London: Cornel UniversityPress, 1975), h. 132. 


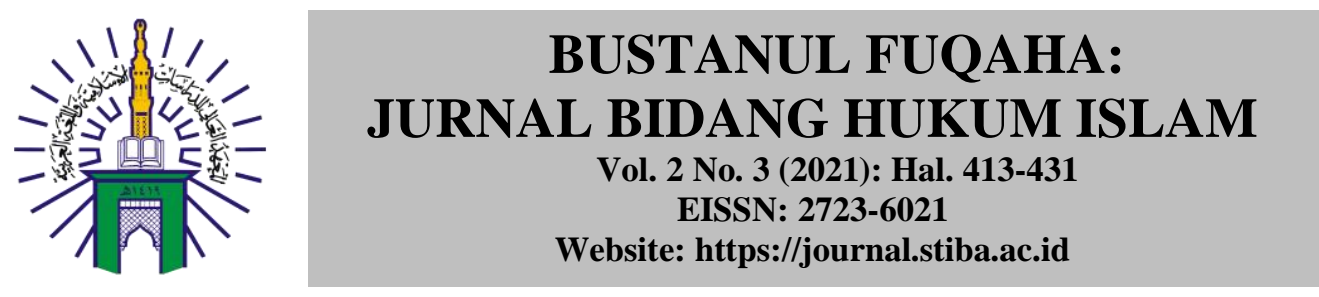

\section{BUSTANUL FUQAHA}

Jurnal Bidang Hukum Islam

dalam suatu buku, atau lebih tepat lagi himpunan kaidah-kaidah Hukum Islam yang disusun secara sistematis selengkap mungkin dengan berpedoman pada rumusan kalimat atau pasal-pasal yang lazim digunakan dalam peraturan perundang-undangan ${ }^{25}$.

Pada tanggal 10 Juni 1991 Presiden RI telah mengeluarkan instruksi Presiden No. 1 Tahun 1991 kepada Menteri Agama untuk: Pertama, menyebarluaskan Kompilasi Hukum Islam yang terdiri dari 3 (tiga) buku: Buku I: tentang Hukum Perkawinan; Buku II : tentang Hukum Kewarisan; Buku III : tentang Hukum Perwakafan Untuk digunakan oleh pemerintah dan masyarakat yang memerlukan. Kedua, melaksanakan instruksi itu dengan sebaik-baiknya dan dengan penuh tanggung jawab.

Lahirnya Kompilasi Hukum Islam (KHI) yang ditetapkan dalam bentuk Instruksi Presiden No. 1 Tahun 1991 adalah untuk memenuhi kebutuhan masyarakat Indonesia (khususnya masyarakat Islam) agar di dalam bidang Hukum Perkawinan, Kewarisan dan Perwakafan didapati ketentuan hukum yang lebih lengkap, pasti dan mantap sesuai dengan sasaran kemerdekaan bangsa Indonesia yang berdasarkan Pancasila dan UUD 1945. Selain di dalam Undang-Undang No. 1 Tahun 1974 tentang Perkawinan, dasar hukum perkawinan juga terdapat di dalam Pasal 2 sampai dengan Pasal 10 Kompilasi Hukum Islam. Pasal 2 kompilasi hukum Islam menyebutkan bahwa: "Perkawinan menurut hukum Islam adalah pernikahan, yaitu akad yang sangat kuat, atau misiaqon golizo untuk menaati perintah Allah dan melaksanakannya merupakan ibadah.”

\section{Konsekuensi Hukum Akibat Putusnya Perkawinan Perspektif UU No. 1 Tahun 1974 Pasal 38-41}

Hubungan suami istri yang telah dijalin dengan pejanjian suci, terkadang tidak menutup kemungkinan akan mengalami pertikaian yang menghantarkan pada perceraian dalam sebuah rumah tangga. Apabila mencermati Pasal $48-41^{26}$ di mana pada setiap pasal akan menyebutkan putusnya perkawinan serta akibatnya, yakni Pasal 38 UU No. 1 Tahun 1974 tentang perkawinan yang menyebutkan bahwa: "Perkawinan dapat putus karena kematian, perceraian, dan atas putusan pengadilan." Perceraian adalah salah satu bentuk dari sebab putusnya perkawinan. Perceraian tentunya juga melahirkan konsekuensi tertentu yaitu harta, hak asuh anak (hadhanah) dan status pernikahan $^{27}$.

Berdasarkan Pasal 39 Undang-Undang Perkawinan, perceraian hanya dapat dilakukan di depan sidang pengadilan setelah pengadilan yang bersangkutan berusaha dan tidak berhasil mendamaikan kedua belah pihak. Sehubungan dengannya, untuk melakukan perceraian, maka harus dilandasi dengan alasan yang kuat bahwa sudah tidak terdapat lagi kecocokan dan persamaan tujuan dalam membina rumah tangga, artinya sudah tidak dapat hidup rukun kembali sebagai pasangan suami-istri.

Gugatan perceraian dapat diajukan dengan alasan-alasan yang dijabarkan dalam penjelasan Undang-Undang No. 1 Tahun 1974 Pasal 39 ayat (2) sebagai berikut:

${ }^{25}$ Tahir Azhary, Kompilasi Hukum Islam Sebagai Alternatif: Suatu Analisis Sumber- Sumber Hukum Islam, Mimbar Hukum No.4 (1991), h. 16.

${ }^{26}$ Tim Redaksi Nuansa Aulia. Kompilasi Hukum Islam, h. 89-97

${ }^{27}$ Nunung Rodliyah, "Akibat Hukum Perceraian Berdasarkan Undang-Undang No 1 Tahun 1947 tentang Perkawinan”, Keadilan Progresif 5, (1 Maret 2014): h. 125. 


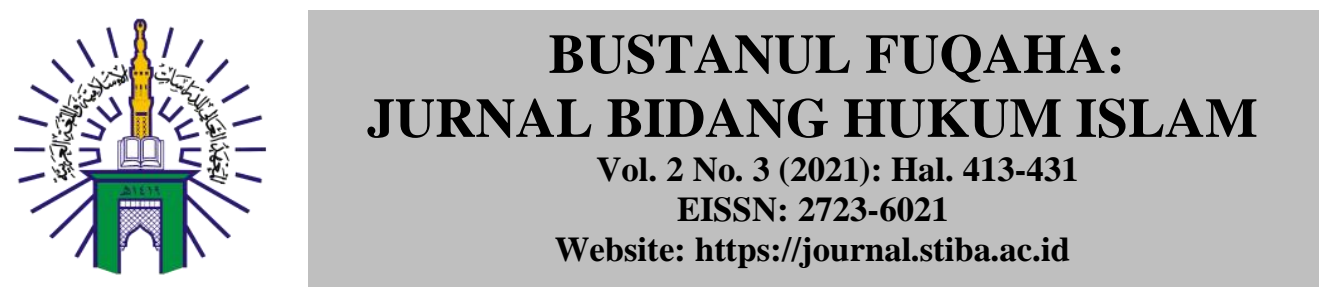

\section{BUSTANUL FUQAHA}

Jurnal Bidang Hukum Islam

1. Salah satu pihak berbuat zina atau menjadi pemabuk, pemadat, penjudi dan lain sebagainya yang sukar disembuhkan.

2. Salah satu pihak meninggalkan yang lain selama dua (2) tahun berturut-turut tanpa izin pihak yang lain dan tanpa alasan yang sah atau karena hal lain di luar kemauannya.

3. Salah satu pihak mendapat hukuman penjara lima (5) tahun atau hukuman yang lebih berat yang membahayakan pihak yang lain.

4. Salah satu pihak melakukan kekejaman atau penganiayaan berat yang membahayakan terhadap pihak yang lain.

5. Salah satu pihak mendapat cacat badan atau penyakit yang mengakibatkan tidak dapat menjalankan kewajibannya sebagai suami atau istri.

6. Antara suami dan istri terus menerus terjadi perselisihan dan pertengkaran dan tidak ada lagi harapan akan hidup rukun lagi dalam rumah tangga.

Pasal 209 Kitab Undang-Undang Hukum Perdata ${ }^{28}$ menyebutkan berbagai alasan yang dapat mengakibatkan perceraian, terdiri atas:

1. Zina.

2. Meninggalkan tempat tinggal bersama dengan iktikad jahat.

3. Penghukuman dengan hukuman penjara lima tahun lamanya atau dengan hukuman yang lebih berat, yang diucapkan setelah perkawinan.

4. Melukai berat atau menganiaya, dilakukan oleh si suami atau si istri terhadap istri atau suaminya, yang demikian, sehingga membahayakan jiwa pihak yang dilukai atau dianiaya, sehingga mengakibatkan luka-luka yang membahayakan.

Dalam hal suatu perkawinan sudah putus karena perceraian, tidaklah mengakibatkan hubungan antara orang tua (suami dan istri yang telah bercerai) dan anak-anak yang lahir dari perkawinan tersebut menjadi putus juga.Sebab dengan tegas telah diatur bahwa suami dan istri yang telah bercerai tetap mempunyai kewajiban sebagai orang tua yaituuntuk memelihara dan mendidik anak-anaknya, termasuk dalam hal pembiayaan yang timbul dari pemeliharaan pendidikan dari anak tersebut.Hanya hak asuh yang pindah ke salah satu pihak yaitu beralih ke ayah atau ibunya.

Pasal 41 Undang-Undang No 1 Tahun 1974 tentang perkawinan disebutkan bahwa akibat dari putusnya perkawinan kaerena perceraian adalah:

1. Baik ibu atau bapak tetap berkewajiban memelihara dan mendidik anak-anaknya, semata-mata berdasarkan kepentingan anak, bilamana ada perselisihan mengenai pengasuhan anak, pengadilan memberi keputusannya.

2. Bapak yang bertanggung jawab atas semua biaya pemeliharaan dan pendidikan yang diperlukan anak itu, bilamana bapak dalam kenyataannya tidak dapat memberi kewajiban tersebut, pengadilan dapat menentukan bahwa ibu ikut memikul biaya tersebut.

3. Pengadilan dapat mewajibkan kepada bekas suami untuk memberikan biaya penghidupan dan atau menentukan sesuatu kewajiban bagi bekas istri.

28 Tim Redaksi BIP, Himpunan Peraturan Undang-Undang Kitab Undang-Undang Hukum Perdata, (Cet.I; Jakarta: Bhuana Ilmu Populuer Kelompok Gramedia, 2018), h. 73. 
Akibat hukum perceraian menurut Undang-Undang No. 1 Tahun 1974 tentang Perkawinan antara lain dapat diuraikan sebagai berikut: ${ }^{29}$

\section{Terhadap Pemeliharaan Anak}

Menurut Undang-Undang Perkawinan, meskipun telah terjadi perceraian bukan berarti kewajiban suami istri sebagai ayah dan ibu terhadap anak di bawah umur berakhir. Suami yang menjatuhkan talak kepada istrinya wajib membayar nafkah untuk anak-anaknya, yaitu belanja untuk memelihara dan keperluan pendidikan anak-anaknya itu, sesuai dengan kedudukan suami. Kewajiban memberi nafkah anak harus terus menerus dilakukan sampai anak-anak tersebut balig dan berakal serta mempunyai penghasilan sendiri. Baik bekas suami maupun bekas istri tetap berkewajiban memelihara dan mendidik anak-anaknya berdasarkan kepentingan anak. Suami dan istri bersama bertanggung jawab atas segala biaya pemeliharaan dan pendidikan anakanaknya. Apabila suami tidak mampu, maka pengadilan dapat menetapkan bahwa ibu yang memikul biaya anak-anaknya.

Sebagaimana yang dijelaskan pada pasal 45 Undang-Undang No. 1 Tahun 1974 tentang Perkawinan bahwa: (1) Orang tua wajib memelihara dan mendidik anak-anak sebaik-baiknya; (2) Kewajiban orang tua yang disebutkan dalam ayat (1) pasal ini berlaku sampai anak itu kawin atau dapat berdiri sendiri, dan kewajiban terus berlaku meskipun perkawinan antara orang tua putus.

Berdasarkan pasal 105 dan 106 Instruksi Presiden Republik Indonesia No. 1 Tahun 1991 tentang Kompilasi Hukum Islam dijelaskan bahwa, Pasal 105 Kompilasi Hukum Islam, dalam hal terjadinya perceraian: (1) Pemeliharaan anak yang belum mumayyiz atau belum berumur dua belas (12) tahun adalah hak ibunya; (2) Pemeliharaan anak yang sudah mumayyiz diserahkan kepada anak mau memilih di antara ayah dan ibunya sebagai pemegang hak pemeliharaannya; (3) Biaya pemeliharaan ditanggung oleh ayahnya. Sementara itu, pada Pasal 106 Kompilasi Hukum Islam menyatakan bahwa: (1) Orang tua berkewajiban merawat dan mengembangkan harta anak- anaknya yang belum dewasa atau di bawah pengampuan, dan tidak diperbolehkan memindahkan atau menggadaikannya kecuali karena keperluan yang mendesak jika kepentingan dan kemaslahatan anak itu menghendaki atau suatu kenyataan yang tidak dapat dihindari lagi; (2) Orang tua bertanggung jawab atas kerugian yang ditimbulkan karena kesalahan dan kelalaian dari kewajiban yang tersebut pada ayat (1).

Adapun pasal 156 Kompilasi Hukum Islam, mengatur tentang pemeliharaan anak ketika ibu kandungnya meninggal dunia dengan memberikan urutan yang berhak memelihara anak, antara lain: (1) Anak yang belum mumayyiz berhak mendapatkan hadhanah dari ibunya, kecuali bila ibunya sudah meninggal dunia, maka kedudukannya digantikan oleh: (a) Wanita-wanita dalam garis lurus ke atas dari ibu; (b) Ayah; (c) Wanita-wanita dalam garis lurus ke atas dari ayah; (d) Saudara perempuan dari anak yang bersangkutan; dan (e) Wanita-wanita kerabat sedarah menurut garis samping dari ayah.

${ }^{29}$ Indonesia, Republik. Peraturan pemerintah nomor 9 tahun 1975 tentang pelaksanaan Undangundang nomor 1 tahun 1974 tentang perkawinan. Up. Indonesia, 1975. 


\section{Terhadap Harta Bersama}

Pasal 1 butir f Kompilasi Hukum Islam menjelaskan bahwa yang dimaksud dengan harta kekayaan dalam perkawinan atau syarikah adalah harta yang diperoleh baik sendiri-sendiri atau bersama suami-istri selama dalam ikatan perkawinan berlangsung dan selanjutunya disebut harta bersama, tanpa mempersoalkan terdaftar atas nama siapapun. Adapun mengenai peraturan tentang harta kekayaan dalam perkawinan secara tegas diatur dalam pasal 85 sampai pasal 97 Kompilasi Hukum Islam sebagai berikut:

a) Pasal 85 Kompilasi Hukum Islam: Adanya harta bersama dalam perkawinan itu tidak menutup kemungkinan adanya harta milik masing-masing suami atau istri.

b) Pasal 86 Kompilasi Hukum Islam: (1) Pada dasarnya tidak ada percampuran antara harta suami dan harta istri karena perkawianan; (2) Harta istri tetap menjadi hak istri dan dikuasai penuh olehnya, demikian juga harta suami tetap menjadi hak suami dan dikuasai penuh olehnya.

c) Pasal 87 Kompilasi Hukum Islam: (1) Harta bawaan dari masing-masing suami dan istri dan harta yang diperoleh masing-masing sebagai hadiah atau warisan adalah di bawah penguasaan masing-masing, sepanjang para pihak tidak menentukan lain dalam perjanjian perkawinan; (2) Suami dan istri mempunyai hak sepenuhnya untuk melakukan perbuatan hukum atas harta masing-masing berupa hibah, hadiah, sedekah atau yang lainnya.

d) Pasal 88 Kompilasi Hukum Islam: Apabila terjadi perselisihan antara suami-istri tentang harta bersama, maka penyelesaian perselisihan itu diajukan kepada Pengadilan Agama.

e) Pasal 89 Kompilasi Hukum Islam: Suami bertanggung jawab menjaga harta bersama, harta istri maupun hartanya sendiri.

f) Pasal 90 Kompilasi Hukum Islam: Istri turut bertanggung jawab menjaga harta bersama maupun harta suami yang ada padanya.

g) Pasal 91 Kompilasi Hukum Islam: (1) Harta bersama sebagaimana tersebut dalam pasal 85 di atas terdapat berupa benda berwujud atau tidak berwujud; (2) Harta bersama yang berwujud dapat meluputi benda tidak bergerak, benda bergerak, dan surat-surat berharga; (3) Harta bersama yang tidak berwujud dapat berupa hak maupun kewajiban; (4) Harta bersama dapat dijadikan barang jaminan oleh salah satu pihak atas izin pihak lainnya.

h) Pasal 92 Kompilasi Hukum Islam: Suami atau istri tanpa persetujuan pihak lain tidak diperbolehkan menjual atau memindahkan harta bersama.

i) Pasal 93 Kompilasi Hukum Islam: (1) Bertanggung jawab terhadap utang suami atau istri dibebankan pada hartanya masing-masing; (2) Pertanggungjawaban terhadap utang yang dilakukan untuk kepentingan keluarga, dibebankan harta bersama; (3) Bila harta bersama tidak mencukupi, maka dibebankan kepada harta suami; (4) Bila harta suami tidak ada atau tidak mencukupi maka dibebankan kepada harta istri.

j) Pasal 94 Kompilasi Hukum Islam: (1) Harta bersama dari perkawinan seorang suami yang mempunyai istri lebih dari seorang, masing-masing terpisah dan berdiri sendiri; (2) Pemilikan harta bersama dari perkawinan seorang suami yang mempunyai istri lebih dari seorang sebagaimana tersebut dalam ayat (1), dihitung 


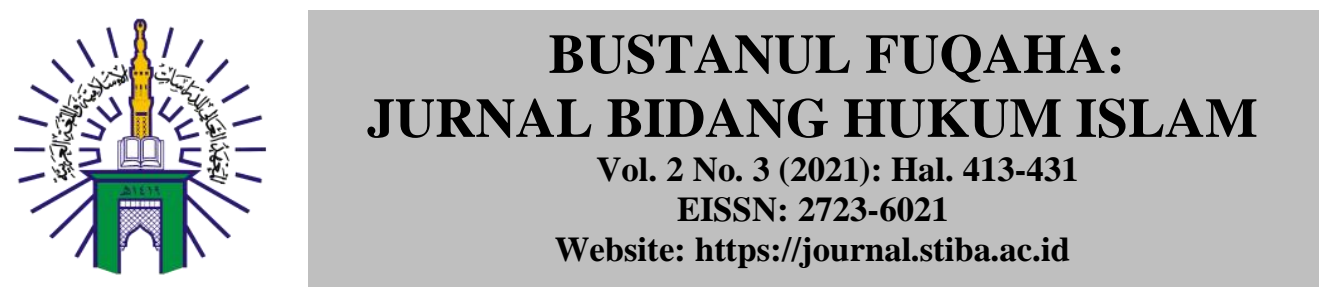

\section{BUSTANUL FUQAHA}

Jurnal Bidang Hukum Islam pada saat akad perkwinan yang kedua, ketiga, atau yang keempat.

k) Pasal 95 Kompilasi Hukum Islam: (1) Dengan tidak mengurangi ketentuan pasal 24 ayat (2) huruf c peraturan pemerintahan No. 9 Tahun 1975 dan pasal 136 ayat (2), suami atau istri dapat meminta Pengadilan Agama untuk meletakkan sita jaminan atas harta bersama tanpa adanya permohonan gugat cerai, apabila salah satu melakukan perbuatan yang merugikan dan membahayakan harta bersama seperti judi, mabuk, boros dan sebagainya; (2) Selama masa sita dapat dilakukan penjualan atas harta bersama untuk kepentingan keluarga dengan izin Pengadilan Agama.

1) Pasal 96 Kompilasi Hukum Islam: (1) Apabila terjadi cerai mati, maka seperuh harta bersama menjadi hak pasangan yang hidup lebih lama; (2) Pembagian harta bersama bagi seorang suami atau istri yang istri atau suaminya hilang harus ditangguhkan sampai adanya kepastian matinya yang hakiki atau matinya secara hukum atas dasar putusan Pengadilan Agama.

m)Pasal 97 Kompilasi Hukum Islam: Janda atau duda cerai hidup masing-masing berhak seperdua dari harta bersama sepanjang tidak ditentukan lain dalam perjanjian perkawinan.

Akibat lain dari perceraian adalah menyangkut masalah harta benda perkawinan khususnya mengenai harta bersama seperti yang ditentukan dalam pasal 37 UndangUndang Perkawinan, bahwa bila perkawinan putus karena perceraian, maka harta bersama diatur menurut hukumnya masing-masing. Menurut penjelasan resmi pasal tersebut, yang dimaksud dengan hukumnya masing-masing adalah hukum Agama, hukum Adat dan hukum lain-lainnya. Memperhatikan pada pasal 37 dan penjelasan resmi atas pasal tersebut Undang-Undang ini tidak memberikan keseragaman hukum positif tentang bagaimana harta bersama apabila terjadi perceraian.

Harta bawaan atau harta asal dari suami atau istri tetap berada ditangan pihak masingmasing. Apabila bekas suami atau bekas istri tidak melaksanakan hal tersebut diatas, maka mereka dapat digugat melalui pengadilan negri di tempat kediaman tergugat, agar hal tersebut dapat dilaksanakan.Mengenai penyelesaian harta bersama karena perceraian, suami-istri yang beragama Islam menurut hukum Islam, sedangkan bagi suami-istri non muslim menurut hukum perdata.

\section{Terhadap Nafkah}

Secara umum pendapat yang masyhur sampai sekarang adalah biaya istri yang telah ditalak oleh suaminya tidak menjadi tanggungan suaminya lagi, terutama dalam perceraian itu menunjukkan bahwa istrinya yang bersalah. Namun, dalam hal istri yang tidak bersalah, maka paling tinggi yang diperolehnya mengenai biaya hidupnya adalah pembiayaan hidup selama ia masih dalam masa idah yang lebih kurang selama sembilan puluh (90) hari. Tetapi sesudah masa idah, suami tidak perlu lagi membiayai bekas istrinya itu. Bahkan sesudah masa idah, bekas istri itu harus keluar dari rumah suaminya andaikata ia masih hidup di rumah yang disediakan oleh suaminya. Ketentuan ini bisa diterapkan dengan damai atas persetujuan bekas suami begitupun mengenai jumlah biaya hidupnya, atau dapat pula dengan putusan perdamaian apabila bekas suami dengan tidak sukarela menyediakan diri untuk memberi biaya hidup tersebut. Ketentuan 


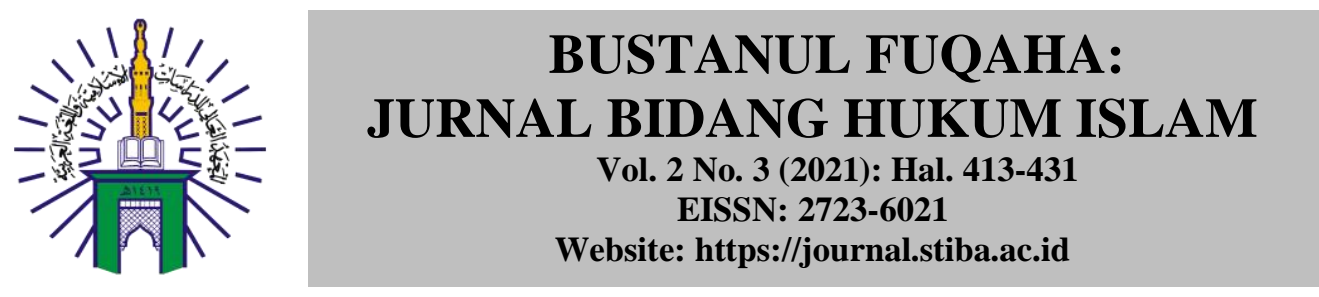

\section{BUSTANUL FUQAHA}

Jurnal Bidang Hukum Islam

kemungkinan pembiayaan sesudah bercerai itu telah diatur dalam Undang-Undang Perkawinan dalam Pasal 41 huruf $\mathrm{C}$, yang berbunyi "Pengadilan dapat mewajibkan kepada bekas suami untuk memberikan biaya penghidupan dan atau menentukan sesuatu kewajiban bagi bekas istri."

Selanjutnya, apabila bekas istri tidak mempunyai mata pencaharian untuk nafkah sehari-harinya maka bekas suami harus memberikan biaya hidup sampai bekas istrinya itu menikah lagi dengan pria lain. Kemudian berdasarkan uraian tersebut dapat dianalisis bahwa akibat hukum perceraian menurut Undang-Undang No. 1 Tahun 1974 tentang Perkawinan dapat dilihat akibat hukumnya: (1) Terhadap pemeliharaan anak, yaitu kedua orang tua wajib memelihara dan mendidik anak-anak mereka sebaikbaiknya yang berlaku sampai anak itu kawin atau dapat berdiri sendiri. Kewajiban tersebut berlaku terus meskipun perkawinan antara kedua orang tua putus. Di mana pemeliharaan anak yang sudah mumayyiz diserahkan kepada anak untuk memilih di antara ayah atau ibunya sebagai pemegang hak pemeliharaannya dan biaya pemeliharaan ditanggung oleh ayahnya; (2) Terhadap harta bersama, pada dasarnya tidak ada percampuran harta suami dan harta istri karena perkawinan di mana harta istri tetap menjadi hak istri dan dikuasai penuh olehnya, demikian juga harta suami tetap menjadi hak suami dan dikuasai penuh olehnya, adapun apabila terjadi perselisihan antara suami-istri tentang harta bersama, maka penyelesaian perselisihan itu diajukan kepada Pengadilan Agama, kemudian pertanggungjawaban terhadap utang suami atau istri dibebankan pada hartanya masing-masing, sedangkan pertanggungjawaban terhadap utang yang dilakukan untuk kepentingan keluarga, dibebankan kepada harta bersama dan bila harta bersama tidak mencukupi, dibebankan kepada harta suami serta bila harta suami tidak ada atau tidak mencukupi dibebankan kepada harta istri.

Akibat lain dari perceraian adalah menyangkut masalah harta benda perkawinan khusnya mengenai harta bersama bahwa bila perkawinan putus akibat perceraian, maka harta bersama diatur menurut hukumnya masing-maasing yaitu menurut hukum Agama, hukum adat dan hukum lain-lainnya; (3) Terhadap nafkah, sebagaimana yang telah disinggung diawal sub bahasan ini.

\section{Perspektif Fikih Munakahat}

Sama halnya pada pembahasan di atas bahwa konsekuensi hukum akibat putusnya perkawinan perspektif Undang-Undang No. 1 Tahun 1974 Pasal 38-41 yakni: berdampak pada anak, harta bawaan dan nafkah.

\section{Dampak terhadap Anak}

Dalam pandangan Islam, anak adalah titipan Allah swt. kepada orang tua, masyarakat, bangsa, negara, sebagai pewaris dari ajaran Islam. Pengertian ini memberikan hak atau melahirkan hak yang harus diakui, diyakini, dan diamankan. Oleh karena itu, anak perlu dididik dan diajari dengan kebaikan. Apabila perkawinan melahirkan anak, maka kedudukan anak serta bagaimana hubungan antara orang tua dengan anaknya itu menimbulkan persoalan, maka diperlukan adanya aturan-aturan hukum yang mengatur tentang hubungan mereka. Selain itu, mengenai hak anak setelah kedua orang taunya bercerai, maka dapat diketahui bahwa hak anak yaitu mendapatkan biaya penghidupan dan pengasuhan atau hadhanah. Hadhanah (pemeliharaan anak) 

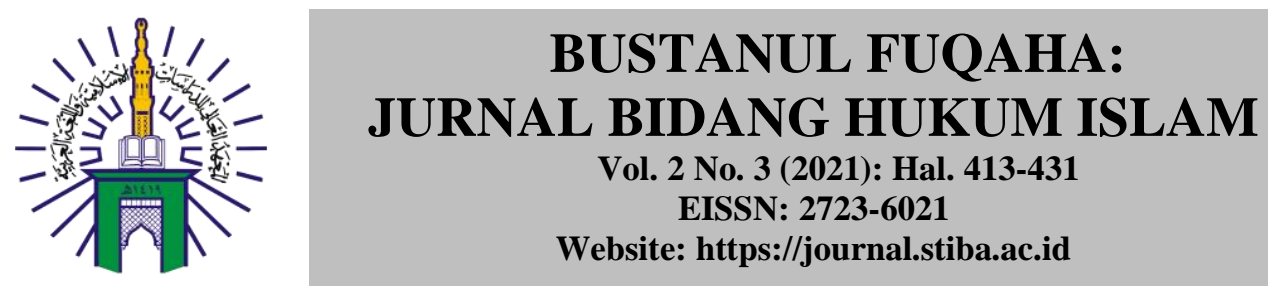

\section{BUSTANUL FUQAHA}

Jurnal Bidang Hukum Islam

merupakan suatu kewenangan untuk memelihara dan mendidik anak yang masih kecil yang belum bisa memenuhi kebutuhan sendiri dan tentunya mengasuh anak orang yang sudah dewasa akan tetapi kehilangan akalnya atau idiot ${ }^{30}$.

Dalam pembahasan fikih, pandangan imam mazhab yakni Imām Hanāfi, Imam Hambali, Imām Syāfi' I, dan Imām Malik perlu diperhatikan. Berdasarkan penelusuran Masalah hadhanah, maka hal ini paling tidak meliputi dua (2) hal yaitu, urutan pemegang hak hadhanah dan syarat mendapatkan hak hadhanah. Pertama, urutan pemegang hak hadhanah, dalam mazhab Hanafiyah, hadhanah ditetapkan bagi kerabat laki-laki/perempuan dengan urutan, yang paling berhak adalah ibu, ibunya ibu, nenek dari ibu dan garis lurus ke atas, nenek dari garis ayah ke atas, saudara perempuan ibu, dan saudara perempuan dari ayah. Sementara mazhab Malikiyah berpendapat yang paling berhak adalah ibunya, ibunya ibu, dan seterusnya dalam garis lurus ke atas, bibi dari ibu, bibinya ibu, ibunya ayah, neneknya ayah. Adapun menurut Syafi'iyah, hak hadhanah di bagi menjadi tiga, yaitu: (1) Berkumpulnya kerabat yang laki-laki dan perempuan, maka didahulukan pihak perempuan; (2) Berkumpulnya kerabat perempuan saja, maka didahulukan ibu kemudian ibunya ibu, nenek ibu, dan seterusnya dalam garis lurus ke atas, nenek dari pihak ayah, saudara perempuan, bibi dari pihak ibu, anak bibi dan seterusnya; dan (3) Berkumpulnya kerabat laki-laki saja, maka ayah didahulukan, kemudian kakek, saudara ayah, saudara ibu, paman dari ayah, paman dari ibudan seterusnya. Terakhir, menurut mazhab Hanbali, yang paling berhak adalah ibu, ibunya ibu, neneknya ibu, ayah dari ibu, ibu dalam garis lurus ke atas, kakek, saudara ibu, saudara ayah dan seterusnya.

Kedua, syarat mendapatkan hak hadhanah ${ }^{31}$, di mana syarat bagi laki-laki dan wanita, yaitu: (1) Balig; (2) Berakal; (3) Mampu mengasuh madhun, maksudnya adalah mampu menjaga akhlak dan kesehatan anak yang di asuh; (4) Memiliki sifat amanah; dan (5) Islam. Sementara syarat khusus bagi wanita, yaitu: (1) Tidak berstatus menikah dengan laki-laki lain yang bukan mahram dari si kecil; (2) Memiliki hubungan darah dengan si kecil; (3) Tidak terhalang dari kegiatan mengasuh si kecil karena alas an tidak mendapatkan bayaran; dan (4) Hadhanah tidak di aksanakan di tempat yang dibenci oleh si kecil, karena itu bisa menyiksa dirinya. Adapun syarat khusus bagi laki-laki, yakni: (1) Mahram bagi si kecil; dan (2) Orang yang mengasuh baik itu ayah atau yang lainnyamasih memiliki anggota keluarga yang pantas melakukan kegiatan pengasuhan dari golongan wanita.

\section{Dampak terhadap Harta}

Harta merupakan segala sesuatu yang dimanfaatkan dalam sesuatu yang legal menurut hukum syara' (hukum Islam) seperti jual beli, pinjaman, konsumsi dan hibah atau pemberian. Harta dari segi bahasa disebut dengan al-Mal yang berarti condong, cenderung dan miring. Nasrun Haroen dengan ungkapan yang berbeda mengungkapkan bahwa al-Mal berasal dari kata mal yang berarti condong atau berpaling dari tengah ke salah satu sisi dan al-Mal diartikan sebagai segala sesuatu yang menyenangkan manusia

\footnotetext{
${ }^{30}$ Nur Rocman, "Batasan Cacat yang Memperbolehkan Putusnya Perkawinan", Skripsi (Semarang: Fak. Syariah dan Hukum UIN Walisongo, 2017), h. 47.

${ }^{31}$ Tim ulin Nuha Ma"had Aly An-Nur, Fikih Munakahat. h. 242.
} 


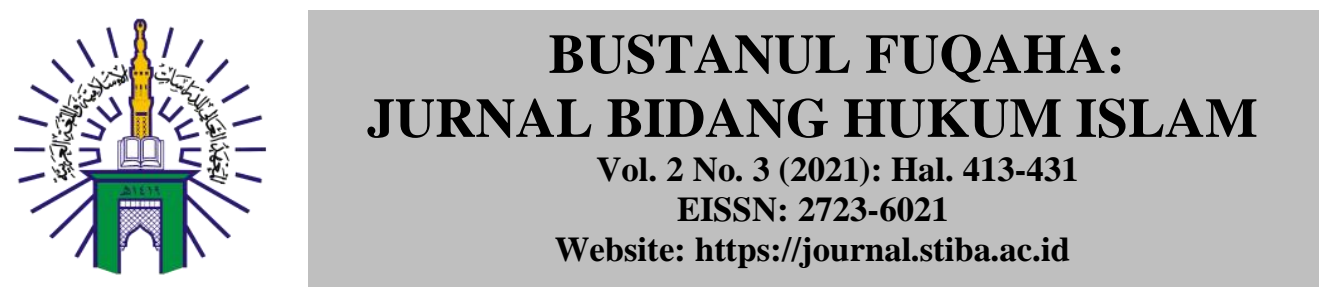

dan mereka pelihara, baik dalam bentuk materi maupun dalam bentuk manfaat ${ }^{32}$.

\section{Dampak terhadap Nafkah}

Dalam masalah pernikahan, nafkah berarti kewajiban suami terhadap istri dan anak dalam bentuk materi. Berdasarkan pengertian tersebut maka seseorang perempuan yang sudah dinikahi secara sah oleh seorang laki-laki berhak untuk mendapatkan nafkah dari suaminya itu ${ }^{33}$. Sebagaimana firman Allah swt. dalam Q.S. al-Baqarah/2:233,

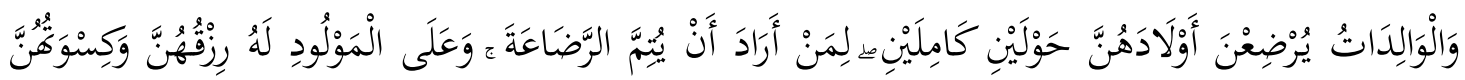

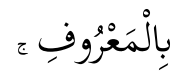

Terjemahan:

"Dan ibu-ibu hendaklah menyusui anak-anaknya selama dua tahun penuh, bagi yang ingin menyusui secara sempurna. Dan kewajiban ayah menanggung nafkah dan pakaian mereka dengan cara yang patut......"34

Ayat di atas menunjukan bahwa seorang suami selain harus memberi nafkah kepada istrinya, maka seorang ayah pun harus memberi nafkah kepada anaknya yaitu dengan pemberian air susu, nafkah, pakaian dan pelayanan. Dalam hukum Islam, timbulnya kewajiban memberikan nafkah oleh orang tua laki-laki (ayah) terhadap anaknya setelah terjadi perceraian adalah disebabkan faktor sebagai keturunannya. Dalam hal ini, perlu pula dilihat mengenai prinsip hukum tentang tanggung jawab biaya nafkah anak setelah terjadinya perceraian.

\section{KESIMPULAN}

Berdasarkan penelitian ini, dapat disimpulkan bahwa perkawinan merupakan ketetapan Allah swt. yang umum dan berlaku pada semua makhluknya, baik pada manusia, hewan, dan tumbuh-tumbuhan dan merupakan salah satu cara yang dipilih oleh Allah swt. sebagai jalan bagi makhluknya untuk berkembangbiak dan melestarikan hidupnya. Secara umum landasan hukum perkawinan yang berlaku di Indonesia dikembalikan sesuai dengan hukum atau agama yang dianut oleh masing-masing pemeluknya, sebagaimana yang tercantum dalam Undang-Undang No 1 Tahun 1974 tentang Perkawinan yang mencantumkan makna dari perkawinan itu sendiri yakni, "Ikatan lahir batin seorang pria dengan seorang wanita sebagai suami istri dengan tujuan membentuk keluarga (rumah tangga) yang bahagia dan kekal berdasarkan Ketuhanan yang Maha Esa."

Terjadinya perceraian akan berdampak pada anak, sehingga eksistensi seorang anak pun dilupakan bahwa anak adalah titipan Allah swt. kepada orang tua, masyarakat, bangsa, negara, sebagai pewaris dari ajaran Islam. Dengan demikian pengertian ini memberikan hak atau melahirkan hak yang harus diakui, diyakini, dirawat, dan dijaga

\footnotetext{
${ }^{32}$ Nasrun Hareon, Fikih Muamalah, (t.Cet; Jakarta: Rajawali, 2005), h. 73

${ }^{33}$ Susi Army Yenti, "Nafkah Anak Akibat Cerai Fasakh Prespektif Hukum Islam",

${ }^{34}$ Departemen Agama Republik Indonesia, Alquran dan Terjemahnya, h. 37.
} 


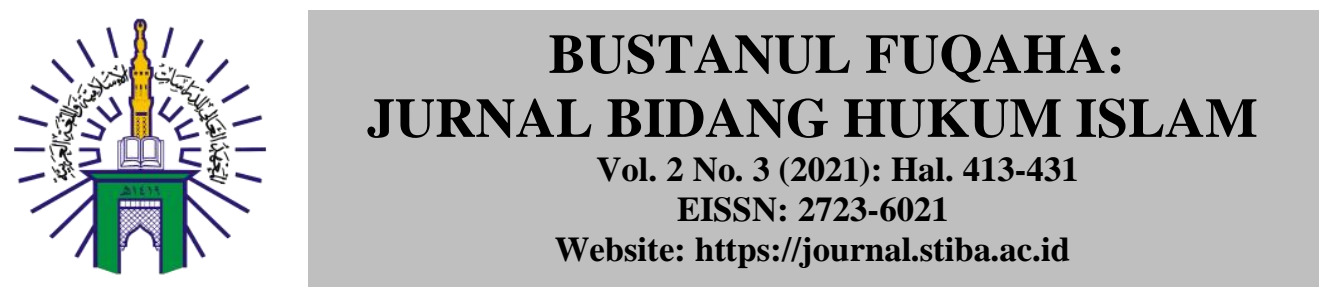

dengan baik.

\section{DAFTAR PUSTAKA}

Abu Daud, Sunan Abu Daud, Cet. I; al-Riyāḍ: Dar Ibn Hazm, 1418H-1997M.

Al-Baihaq̄î, Ahmad bin al-Husain bin 'Ali. al-Sunan al-Kubrāa, Cet. III; Beirut: Darul Kutub al-'Ilmiyyah, 1424H-2003M.

Al-Bukhārī , Muhammad Bin Islmail, Shahih Al-Bukhori Kitāb Al-Ahkām, Dar Al-Fikr.

Al-Darimi, Abu Muhammad. Sunan ad-Dārimī, Juz II. Beirut, Libanon: Dār al-Fikr, 1995.

Al-Ghamidi, Ali bin Sa'id. Dalīl al-Mar'ah al-Muslimah, terj. Ahmad Syarif, dkk, FikihWanita. Cet. IX; Solo: Aqwam, 1438 H/2017 M.

Al-Hajjaj, Muslim bin. Sạhịh Muslim. Juz IV. t.t.: Dār Ihya al-Kutub al-,AArabiyyah, t.th. Al-Munawwir, Ahmad Warson. Kamus al-Munawwir Arab-Indonesia Terlengkap. t.Cet; Yogyakarta: Pustaka Progressif, 1997.

Al-Nasa'i, Al-Sunan al-Nasa'i. ed.'." Abd al-Fatah Abu Ghudah. Halab: Maktab alMatbu 'at al-Islamiyyah, 1986.

Al-Qazwīn̄̄, Abī Abdillah Muhammad bin Yazīd. Sunan Ibnu Mājah, Juz 1. Cet. II; Riyāḍ: Syarikah al-Tibāae ah al-,,Arabiyyah al-Su“ēudiyyah, 1404 H/ 1984M.

Al-Șan'āni, Sayyid al-Imām Muhammad bin Ismail.Subul al-Salam fi al-SyarhBulugu al-Marāmmin Jāmī’ Adillati al-Ahkām, Juz 3. t. Cet; Kairo: Dar Ikhya" al-Turas al-Islami, 1960.

Al-Tirmidzi, Muhammad bin 'Īsā. Sunan al-Tirmidzi, Jilid III. Cet. II, T.tp.: Syarikah Maktabah wa Mathba'ah muștafā al-Bābī, 1975 M.

Andalusi, Imam Abī al-Walīd Muhammad bin Ahmad bin Muhammad bin Ahmad bin Rusydi al-Qurubī. al-Bidāyah al-Mujtahidwa Kifayāh al- muqtaṣid, Juz 2. Cet. I; al-Qāhirah: Dar ibn al-Jauzi, 2004.

Aqmal, Fasakh Nikah Menurut Imam Asy Syafi'i Relevansinya dengan Kompilasi Hukum Islam, Skripsi, Universitas Negeri Alauddin Makassar, 2012.

Azhary, Tahir. Kompilasi Hukum Islam Sebagai Alternatif: Suatu Analisis SumberSumber Hukum Islam, Mimbar Hukum No.4, 1991.

Departemen Agama Republik Indonesia. Alquran dan Terjemahnya. Cet. I; Bandung: Syamil al-Qurean, 2012.

Echols, John. M, \& Hasan Shaldy, English-Indonesia Dictionary. t. Cet; Ithaca dan London: Cornel University Press, 1975.

Hakim, Rahmat.Hukum Perkawinan Islam.Bandung: Pustaka Setia, 2000.

Hambal, Imam Ahmad Bin, Al-Musnad, jilid 4, Bairut, Al-Maktabah Al-Islami, Lebanon Hamid, Zahry. Pokok-Pokok Hukum Nikah Islam danUndang-UndangNikah di Indonesia.t. Cet; Yogyakarta: BinaCipta, 1978.

Hareon, Nasrun. Fikih Muamalah. t.Cet; Jakarta: Rajawali, 2005.

Indonesia, Republik. Peraturan pemerintah nomor 9 tahun 1975 tentang pelaksanaan Undang-undang nomor 1 tahun 1974 tentang perkawinan. Up. Indonesia, 1975.

Matondang, Armansyah. "Faktor-faktor yang mengakibatkan perceraian dalam perkawinan." JPPUMA: Jurnal Ilmu Pemerintahan dan Sosial Politik UMA (Journal of Governance and Political Social UMA) 2.2 (2014): 141-150. 

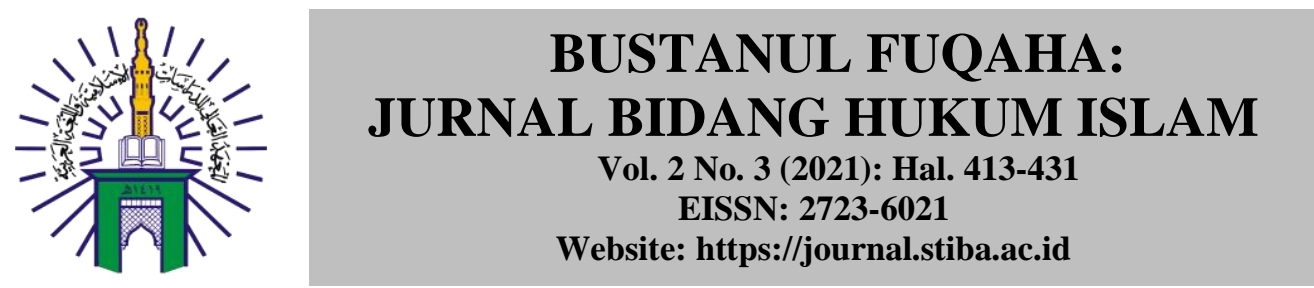

Rocman, Nur. Batasan Cacat yang Memperbolehkan Putusnya Perkawinan, Skripsi. Semarang: Fak. Syariah dan Hukum UIN Walisongo, 2017.

Rodliyah, Nunung. "Akibat Hukum Perceraian Berdasarkan Undang-Undang No 1 Tahun 1947 tentang Perkawinan", Keadilan Progresif 5, 1 Maret 2014.

Rofiq, Ahmad. Hukum Islam di Indonesia. Cet. I; Jakarta: Raja Grafindo, 1995.

Sayyid Sābiq, Fiqh al-Sunnah,Jilid 3. Cet. IV. Beirut: Dār al-Fikr. 1983 M.

Sya'ban, Zakiyuddin. Az Zawaj wa Ath Thalaq Fil Islam, (Riyadh: Dar Al Maktabah, 2009).

Syarifuddin, Amir. Hukum Perkawinan Islam di Indonesia.Jakarta: Kencana, 2007.

Țalib, Sayuti. Hukum Kekeluargaan Indonesia.Cet. V; Jakarta: UI Press, 1986.

Tihami dan Sohari Sahrani.Fikih Munakahat.Jakarta: PT.Rajawali Pers,2010.

Tim Redaksi BIP, Himpunan Peraturan Undang-Undang Kitab Undang-Undang Hukum Perdata. Cet.I; Jakarta: Bhuana Ilmu Populuer Kelompok Gramedia, 2018.

Tim Redaksi Nuansa Aulia. Kompilasi Hukum Islam. Cet.VII; Bandung: CV. Nuansa Aulia, 2017.

Tim Ulin Nuha Ma'had 'Aly An-Nur. Fiqih Munakahat. Cet. I; Solo: Kiswah Media, 2018.

Uwaidah, Kamil Muhammad. al-Jāmi' Fi al-Fiqhi al-Nisā'.Cet. I; Lebanon: Darul Kutub al-Ilmiyyah, 1417 H/1996 M.

Yenti, Susi Army. Nafkah Anak Akibat Cerai Fasakh Prespektif Hukum Islam, Skripsi. Batusangkar: Fak. Syariah dan Hukum Institut Agama Islam Batusangkar, 2017.

Zulfina, Noorish. Kedudukan Hukum Putusnya Perkawinan dalam Putusan Hakim yang Dijatuhkan pada saat istri Hamil (Studi Kasus Perkara Pengadilan Agama Depok No. 532/Pdt.G/2008/PA.Bgr, No 19/Pdt.G/2008/PA.Ngr, dan no 1974/pdt.G/2009/PA.Jr), Skripsi. Universitas Indonesia 2012.

\section{Sumber Online}

https://tafsirq.com/4-an-nisa/ayat-3

https://tafsirq.com/51-az-zariyat/ayat-49

https://tafirq. scom/24-an-nur/ayat-32 